\title{
Interaction Effect of Brain Hemispheric Dominance and Home Environment on Academic Achievement in Mathematics
}

\author{
Parvinder Singh \\ P. G. Department of Mathematics, S.G.G.S. Khalsa College, Mahilpur. (Hoshiarpur), Punjab, India
}

\begin{abstract}
Brain hemispheric dominance and home environment are student level variables and are of great significance concerning scholastic achievement of the students. Analysis with interaction effect of the Brain hemispheric dominance and home environment with academic achievement in mathematics was ended up in this study and discovers that there is a significant interactional relationship between academic achievement in mathematics and combined effect of brain hemispheric dominance and home environment of a student.
\end{abstract}

Keywords: Brain Hemispheric Dominance, Academic Achievement, Home Environment

\section{Introduction}

The term „Mathematicse may be defined in a number of ways. It is an exact science which is related to measurements, calculations, discovering relationships and dealing with the problems of space. According to New English Dictionary, "Mathematics-in a strict sense-is the abstract science which investigates deductively the conclusions implicit in the elementary conception of spatial and numerical relations." In the beginning of our knowledge of mathematics is based on our observations of physical and social environment i.e. it arises out of practical applications. We form certain intuitive ideas or notions known as axioms and postulates. These are self-evident truths.

\section{Nature of Mathematics}

Starting from axioms and postulates we proceed to build up the structure of mathematics by a process of deductive reasoning. Mathematics in the making is not a deductive science; it is an inductive, experimental science and guessing is the experimental tool of mathematics, mathematicians like all other scientists form their theories from bunches analogies and simple examples. They work out their rigorous proofs only after they are pretty confident that what they are trying to prove is correct and in writing these they use only the bulldozer of logical deduction.

\section{Achievement in Mathematics}

Academic superiority or academic success presently becomes directory of child's future in the competitive system. Now it becomes most vital goal of our instructive system that every individual is anticipated to achieve good in academics. Assessment of academic success is a key instrument of our instructive system through which student learns about their aptitude, ability and capability. To optimize academic attainment parents and teachers and instructive planners has a big role to play. Modern period is an era of science and technology; every apprentice must need to do better than in science and mathematics. Academic success in the present socio-economic and educational context is of foremost significance. Dictionary of Behavioral Sciences (Wolfman, 1973) defined academic success as the level of proficiency attained in some specific area concerning educational domain such as reading, mathematics, science and social studies, language or some other subject.

\section{Brain Hemisphericity}

Brain hemisphericity or the cerebral dominance of an individual is described as the retaining and processing of information with diverse modes in his own approach of learning and thinking. Researchers have revealed that the human with left cerebral hemispheric dominance are specific for primarily in verbal, analytical, abstract, temporal and digital operations (Bogen 1969, Gazzaniga 1970). The same study shows that the right cerebral hemispheric dominant human being is specialized for primarily non-verbal, holistic, concrete, creative, analogical and aesthetic function. For identifying the hemispheric dominance, the behaviour in which levels the information is being processed by the individuals is to be considered.

\section{Brain Hemispheric Dominance}

Brain dominance is the use of the different sides of the brain in learning and listening patterns that is to mean, the consistent use one side of the brain over the other. Herrmann (1995) Brain dominance was expressed in terms of how we prefer to learn, understand and express something. The term brain dominance is used to depict the thinking modes of the brain. Although a function of the brain may depend more on one hemisphere than the other, the notion that one hemisphere is dominant and the other is non dominant is possibly too unsophisticated for describing most tasks. Certain individuals possess virtues that make them twice dominant. Their favoured style of thinking allows them to use both sides of the hemispheres equally. Individuals that display twofold dominance are able to use both sides of the brain to logically process thoughts and create intrinsic values and decisions. This stage is called whole brain dominance or integrated brain dominance.

\section{Volume 4 Issue 11, November 2015}




\section{International Journal of Science and Research (IJSR) \\ ISSN (Online): 2319-7064}

Index Copernicus Value (2013): 6.14 | Impact Factor (2014): 5.611

\subsection{Functions of the Left Hemisphere}

Each Hemisphere is capable of functioning in a manner different from the other. For many years attention was focused on the left hemisphere in which speech was localized, the so called ,dominante, ,leading ${ }^{\text {ee }}$ or ,major ${ }^{\text {ee }}$ hemisphere. It was hypothesized that this hemisphere is primarily responsible for the processing of language and planning. These are the two functions which clearly distinguishes men from the rest of the animal kingdom. It has been found to be anatomically larger than the right hemisphere, as evidenced by neonatal studies (Geschwind, 1972). It is considered to be more self-motivated than the right hemisphere in most adults, as indicated by EEG analysis.

\subsection{Functions of the Right Hemisphere}

The right cerebral hemisphere, which controls the left side of the body, is called the mirror, subordinate or mute side because it cannot verbalize what it knows. This was found by Geschwind (1970) that the right hemisphere is anatomically smaller than the left hemisphere. Research has indicated that the right hemisphere had remained underestimated and even today neurophysiologists are of the view that the right hemisphere is a mere unconscious automation while we live in left hemisphere. Goldberg and Costa (1981) concludes that the right hemisphere had a great neuronal capacity to deal with informational complexity.

\subsection{Whole Brain}

Some people use right as well as the left brain as per the existing situation and particular mission to execute. Such people we call them whole brained or integrated brain dominant or the balanced use of brain hemispheric dominance is called whole brain dominance. Our personality can be thought of as a result of the degree to which these left and right brains interact. It is a simplification to identify "left brain" who are very analytical and orderly persons. We similarly know that the artistic, unpredictability and creativity of "right brain" persons. But each of us draws upon specific sides of our brain for a variety of daily functions, depending upon such things as our age, education and life experiences. The choice that which brain is in control of which circumstances and that forges our personality and determines our character.

\subsection{Home Environment}

Home environment refers to climate prevailing in the house of a student, which vary from culture to culture and family to family (Moss and Moss, 1986). According to Makstrot (1989) "Home is a microcosm where children can experience their effectiveness and power to make a difference through problem solving service and cooperation. When parents engender respect for the range of people es needs and life styles, children develops a sense, a purpose, and uses their ability for the benefit of the people of the world as well as themselves

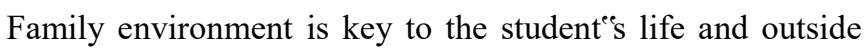
school; it is the most important influence on student's learning and include factors as socio economic status, his parents versus single parent's households, divorce, parenting practices and aspirations, maternal characteristics, family size, and neighborhood (Majoribanks, 1996). In addition high parental aspirations have been associated with increasing student's interest in education (Majoribanks, 2005). Maternal characteristics are another key factor that effect academic achievement. Mothers who are more educated and have higher self esteem have children who receive higher test scores (Eqmon, 2005).

\section{Review of Literature}

Kolappan (2011) in his study analyses the academic attainment and home environment for higher secondary students in Namakkal district of Tamilnadu. Using statistical measures like Mean, Median, Standard Deviation and t-test study indicate that there is a significant difference between home environment and score of boys and girls from urban and rural school students.

Saini (2012) undertake a study concerning academic attainment of scheduled caste students in relation to study habits and home environment. Study reveals that there is no significant association between study habits and academic attainment of scheduled caste students and there is significant association between home environment with its different dimensions.

Kumar (2013) completed a study to find out the effect of home environment, school environment and study habits on academic attainment of students. Study reveals that there was no significant relationship between study habits and academic achievement. Home environment had significant effect on academic attainment but school environment does not play a significant role in academic attainment.

Gurdeep kaur \& Brij Lal (2013) studied the association of style of learning and thinking (SOLAT) in the right cerebral dominance with attainment in mathematics, creativity and right or left handedness among school children. Study indicates that high achievers school children be different from low achiever school children on style of learning and thinking in their right cerebral dominance. It may be due to the reason that achievement in mathematics depends upon right cerebral dominance of school children in processing different modes of information and mathematical operations.

Humera (2015) in his study of hemispheric dominance and mathematics achievement of 10th students of Aurangabad city. Study reveals that greater part of the students have right hemispheric dominance style of learning and thinking. No significant difference was found between mathematics achievement of students with respect to different hemispheric dominant style of learning and thinking. No significant difference was found between mathematics achievement of girls and boys.

\subsection{Objectives of the Study}

The present study was undertaken by keeping in view the following objectives: 


\section{International Journal of Science and Research (IJSR) \\ ISSN (Online): 2319-7064}

Index Copernicus Value (2013): 6.14 | Impact Factor (2014): 5.611

- To study the level of Brain Hemispheric Dominance of Secondary Stage Students.

- To study the relationship between achievement in Mathematics and Brain Hemispheric Dominance.

- To study the relationship between achievement in Mathematics and Home Environment.

- To study the interactional effect of brain hemispheric dominance and home environment on achievement in mathematics.

\subsection{Hypotheses of the Study}

On the basis of above mentioned objectives the following null hypotheses have been framed.

H1: There is no significant difference between levels of brain hemispheric dominance of the students of secondary stage.

$\mathrm{H} 2$ : There is no significant relationship between achievement in mathematics and brain hemispheric dominance.

H3: There is no significant relationship between achievement in mathematics and home environment of the students.

H4: There is no significant interactional effect of brain hemispheric dominance and home environment achievement in mathematics.

\subsection{Tool used}

The following research tools were used to collect data for the present study

1. Brain Hemispheric Dominance Test. (D.Venkataraman, 1994).

2. Home Environment Inventory ( K.S. Mishra, 1989)

\subsection{Sample}

In the present study a sample of 600 students was selected from class XI and XII out of the Government and NonGovernment Secondary Schools of Hoshiarpur, Jalandhar and Nawanshahar districts. 200 students were selected from each of these district out of which 100 are boys and 100 are girls

\section{Results and Discussion}

In this section by using various statistical techniques various hypotheses of the study was verified as under:

Table: 1.1 Distribution of the male and female students in terms of level of brain hemispheric dominance

\begin{tabular}{|c|c|c|c|c|}
\hline Sex & $\begin{array}{c}\text { Right } \\
\text { Dominance }\end{array}$ & $\begin{array}{c}\text { Left } \\
\text { Dominance }\end{array}$ & $\begin{array}{c}\text { Whole } \\
\text { Dominance }\end{array}$ & Total \\
\hline Boys & $216(49.3 \%)$ & $58(61.7 \%)$ & $26(38.2 \%)$ & 300 \\
\hline Girls & $222(50.7 \%)$ & $36(38.3 \%)$ & $42(61.8 \%)$ & 300 \\
\hline Total & $438(73.0 \%)$ & $94(15.7 \%)$ & $68(11.3 \%)$ & G.T. $=600$ \\
\hline
\end{tabular}

Chi Square $=8.996, d f=2, \mathrm{p}=0.011<0.05$

\section{Hypothesis H1:}

Table 1.1 indicates that among all 600 students 438(73.0\%) was found to be right brain dominant, among them $222(50.7 \%)$ were the girls and $216(49.3 \%)$ were the boys correspondingly. 94(15.7\%) students of the total were found to be left brain dominant and among them 58(61.7\%) were the boys and $36(38.3 \%)$ of the students were girls. The proportion of whole brain dominant students were $68(11.3 \%)$ of the total students and out of them $42(61.8 \%)$ were the girls and $26(38.2 \%)$ were the boys. Therefore it is observed from the table 1.1 that majority of the girls were whole brain dominant and on being right brain dominance approximately both the sexes are in equal proportion. Hence by using Chi square hypothesis $\mathrm{H} 1$ is rejected.

Table 1.2: Correlation analyses of the academic achievement in mathematics and the brain hemispheric dominance

\begin{tabular}{|c|c|c|c|c|}
\hline & & $\begin{array}{c}\text { Right } \\
\text { Dominance }\end{array}$ & $\begin{array}{c}\text { Left } \\
\text { Dominance }\end{array}$ & $\begin{array}{c}\text { Whole } \\
\text { Dominance }\end{array}$ \\
\hline $\begin{array}{c}\text { Academic } \\
\text { achievement } \\
\text { in } \\
\text { mathematics }\end{array}$ & $\begin{array}{c}\text { Karl- } \\
\text { Pearson Co- } \\
\text { efficient of } \\
\text { correlation }\end{array}$ & -0.069 & 0.069 & 0.026 \\
\hline & P value & 0.093 & 0.091 & 0.531 \\
\hline & $\mathrm{N}$ & 600 & 600 & 600 \\
\hline
\end{tabular}

\section{Hypothesis H2:}

Table 1.2 shows that the null hypothesis $\mathrm{H} 2$ was accepted as there no significant relationship was established among the brain hemispheric dominance and their academic achievement in mathematics. It was analyzed that the correlation co-efficient between the academic achievement in mathematics and the right brain dominance was $r=-0.069$ which is negative and not significant at .05 and .01 level of significance. Correlation co-efficient between the academic achievement in mathematics and left brain dominance was $r$ $=0.069$ which is positive and not significant and lastly the correlation co-efficient of the whole brain dominance of the students and their academic achievement in mathematics was $\mathrm{r}=0.026$ which is also positive and not significant at any level of significance.

Table 1.3: ANOVA analysis of academic achievement on basis of Home Environment scores

\begin{tabular}{|c|c|c|c|c|}
\hline Category & $\mathbf{N}$ & Mean & SD & F Test \\
\hline $\begin{array}{l}\text { Very High Home } \\
\text { Environment }\end{array}$ & 60 & 67.83 & 8.73 & \multirow{7}{*}{$\begin{array}{c}2.983 \\
\mathrm{P}=3.124 \\
\text { Significant }\end{array}$} \\
\hline High Home Environment & 86 & 87.98 & 9.69 & \\
\hline $\begin{array}{c}\text { Above Average Home } \\
\text { Environment }\end{array}$ & 142 & 73.24 & 10.13 & \\
\hline $\begin{array}{l}\text { Average Home } \\
\text { Environment }\end{array}$ & 156 & 72.41 & 11.24 & \\
\hline Low Home Environment & 96 & 52.57 & 8.44 & \\
\hline $\begin{array}{l}\text { Very Low Home } \\
\text { Environment }\end{array}$ & 60 & 49.87 & 7.37 & \\
\hline Total & 600 & 76.45 & 13.87 & \\
\hline
\end{tabular}

\section{Hypothesis $\mathbf{H 3}$ :}

Table 1.3 shows that the mean score with very high home environment is 67.83 with standard deviation of 8.73 , with high home environment mean score is 87.98 with standard deviation of 9.69 , with above average home environment mean score is 73.24 with standard deviation of 10.13 , with average home environment mean score is 72.41 with standard deviation of 11.24, with low home environment mean score is 52.57 with standard deviation of 8.44 and with very low home environment mean score is 49.87 with standard deviation of 7.37. As F value is 2.983 and $p$ value is 3.124 which is significant at .01 level of significance therefore null hypothesis assumed H3 is rejected and study

\section{Volume 4 Issue 11, November 2015}




\section{International Journal of Science and Research (IJSR) \\ ISSN (Online): 2319-7064 \\ Index Copernicus Value (2013): 6.14 | Impact Factor (2014): 5.611}

shows that there is significant relationship among the different levels of home environment of the students with their academic achievement scores in mathematics.

Table 1.4: ANOVA analyses with interaction effect of the brain hemispheric dominance and home environment on academic achievement in mathematics

\begin{tabular}{|c|c|c|c|c|c|}
\hline Source & $\begin{array}{c}\text { Type III Sum } \\
\text { of Squares }\end{array}$ & $d f$ & Mean Square & $F$ & P value \\
\hline $\begin{array}{c}\text { Corrected } \\
\text { Model }\end{array}$ & $9462.417^{\mathrm{a}}$ & 17 & 556.613 & 2.787 & 0.000 \\
\hline Intercept & 1169832.886 & 1 & 1169832.886 & 5.85723 & 0.000 \\
\hline Dominance & 58.076 & 2 & 29.038 & 0.145 & 0.865 \\
\hline $\begin{array}{c}\text { Home } \\
\text { Environment }\end{array}$ & 3079.782 & 5 & 615.956 & 3.084 & 0.009 \\
\hline $\begin{array}{c}\text { Dominance* } \\
\text { Home } \\
\text { Environment }\end{array}$ & 4918.734 & 10 & 491.873 & 2.463 & 0.007 \\
\hline $\begin{array}{c}\text { Error } \\
\text { Total }\end{array}$ & 116035.049 & 581 & 199.716 & & \\
\hline $\begin{array}{c}\text { Corrected } \\
\text { Total }\end{array}$ & 125497.466 & 598 & & & \\
\hline
\end{tabular}

\section{Hypothesis $\mathrm{H} 4$}

Table 1.4 shows that the null hypothesis assumed $\mathrm{H} 4$ is rejected as there is significant interactional effect $(\mathrm{p}=0.007$ $<0.05$ ) of the brain hemispheric dominance and home environment is reveled for the academic achievement in mathematics of the students. Thus it is concluded that combined effect of the brain hemispheric dominance and home environment has strong association with academic achievement in mathematics.

\section{Conclusions}

From the above study it was concluded that

- Majority of the boys are left brain hemispheric dominant.

- Majority of the girls are of whole brain hemispheric dominant.

- Being right brain hemispheric dominance approximately both the sex are in equal proportion.

- There is no significant relationship between academic achievement in mathematics and brain hemispheric dominance.

- There is significant relationship among the different categories of home environment of the students with their academic achievement in mathematics.

- There is significant relationship between academic achievement in mathematics and combined effect of brain hemispheric dominance and home environment.

\section{References}

[1] Bogen, J.E. (1972). The other side of the brain -II, 94 an appositional mind, bulletin of the angels, neurological society, vol, 34, 1972, 135-162.

[2] Ferrer, F.P. (2014). Correlation of learneres brain dominance and mathematics performance. An investigation in educational setting, International journal of innovative and scientific research. ISSN 2351-8014, 2, p, 287-292.

[3] Gabbard,C.(1997). Coming to terms with Laterality. The Journal of Psychology,.31,561-564.
[4] Gazzaniga, M.S. (1970). The Bisected Brain, New York: Appleton -century crofts

[5] Herrmann,N.(1995).The Creative Brain. Kingsport Tennessee Quebecor Printing Group.

[6] Kalappan, S.(2011). Factors relating to academic achievement and home environment in economics of higher secondary students: International journal of management research and development. ISSN 2248938.

[7] Kaur, K., \& Shikha, D. (2012). Study of personality and hemispheric preferences among science and arts stream students. Indian journal of innovations and developments. 1(10). ISSN : 2277-5390.

[8] Kaur, G. \& Lal, B., (2014). Style of learning and thinking of school children in relation to achievement in mathematics, creativity and right or left handedness. International journal of teacher educational research. 3(5), ISSN, 2919-4642. Retrieved from http://ijter.com/pdf\%20files\%20folder/MAY2014/P3.pd $\mathrm{f}$

[9] Majoribanks, K. (1996). Family learning environment and student's achievement: A Review journal of comparative family studies 27 (2),p. 373-394.

[10] Majoribanks, J. (2005). Correlates among family environment, academic achievement and academic attainment in large sample of young Australian adults. Retrieved from www.google.co.in on 01/01/2013.

[11] Moos,R.H.,\& Moos,B.S.(1986).Family environment scale manual, Consulting psychological press.

[12] Ranhotra K.S .(1996). Career making as related to career maturity, intelligence, Self concept, family environment and academic achievement at +2 stage. Unpublished doctoral thesis, Panjab University, Chandigarh.

[13] Saini, M. (2012) A study of academic achievement of scheduled castes secondary students in relation to study habits, home environment and school environment, Maharishi Dayanand University, Rohtak. 